\title{
Language motivation and attitudes: a study with English for Academic Purposes learners
}

\author{
Flávia Azeredo Cerqueira \\ Johns Hopkins University \\ flavia_azeredo@jhu.edu \\ Shellwyn Badger \\ Universidade Federal de Minas Gerais \\ shellwyn@gmail.com
}

\begin{abstract}
The study investigates English for Academic Purposes (EAP) course learners' motivation within the L2 Motivational Self System Framework (cf. DÖRNYEI; CLÉMENT, 2001; DÖRNYEI, 2005; CSIZÉR; DÖRNYEI, 2005b) and their achievement. The framework consists of three components, of which the ideal L2 self is the most important in the maintenance of motivation. Brazilian learners of EAP, students of a federal university in Belo Horizonte, participated in the study. The data was collected by means of questionnaires about attitude and motivation towards the L2, L2 learning and EAP, and also the ethnicity and socioeconomic backgrounds of learners. The EAP course as a program component of a broader, federal Brazilian policy with both national and international stakeholders was also examined. The results suggest that the learners possess a well-established ideal L2 self. The variables measured in this project presented a positive tendency towards L2 motivation. This confirms that the participants were motivated to learn the L2 language, in this case English. The socioeconomic and ethnic variables indicate that whites from a middle-class background are the majority group on campus. Recommendations for further research in L2 motivation and policy studies conclude the paper.
\end{abstract}

Keywords: EAP. Educational policy. International education. L2 motivational self system. Language attitudes. L2 learning. 


\section{Resumo}

Este estudo investiga a motivação de aprendizes de Inglês para Fins Acadêmicos (IFA) a partir do Modelo de Autossistema Motivacional na L2 (DÖRNYEI; CLÉMENT, 2001; DÖRNYEI, 2005; CSIZÉR; DÖRNYEI, 2005b) e o aproveitamento dos aprendizes no curso. O modelo de Autossistema Motivacional na L2 consiste de três componentes, nos quais o self ideal na L2é o mais importante para a manutenção da motivação. Os participantes do estudo eram aprendizes brasileiros de IFA, estudantes de uma universidade em Belo Horizonte. Os dados foram coletados em questionários sobre atitude e motivação em relação à L2, aprendizagem de L2 e IFA, bem como informações dos participantes a respeito de questões de etnia e situação socioeconômica. Foi examinado também o curso IFA como componente de um amplo programa de política federal com foco nacional e internacional. Os resultados sugerem que os participantes apresentam um self ideal na L2 bem estabelecido. As demais variáveis indicaram uma tendência positiva em relação à motivação. Esse dado confirma que os participantes estavam motivados para aprender a L2. As variáveis socioeconômicas e étnicas indicaram que os estudantes brancos, de classe média representam o grupo majoritário presente no campus universitário estudado.

Palavras-chave: IFA. Políticas educacionais. Educação internacional. Modelo de Autossistema Motivacional na L2. Atitude linguística. Aprendizagem de L2.

\section{Introduction}

Brazil is poised for leadership in the global context; in fact, Brazil has recently been viewed as one of the four most rapidly developing nations, along with Russia, India, China and South Africa (coined 'BRICSA' nations). As the English language is widely used for international communication, especially in the economic and scientific sectors, Brazil is making a concerted effort to increase its citizens' English language skills to expand participation at foreign educational institutions and within the global marketplace. The Brazilian Federal Educational policy Science Without Borders (SWB) aims to multiply Brazilian students' participation at international universities by offering free academic English courses at federal universities to qualifying students. 
Recent information from the Ministry of Education (MEC) suggests that university students are not participating in foreign academic opportunities due to a perceived lack of English language skills, which is a requirement of the foreign institutions. In other words, Brazilian college students do not possess the minimum level of proficiency in English measured largely by a Test of English as a Foreign Language (TOEFL) exam score to study at foreign universities. The Brazilian federal government has partnered with its federal universities to quickly develop policies and programs to meet this need. Therefore, programs such as SWB have scholarships that currently remain unfulfilled. A specific program, aptly named English Without Borders (EWB), has been developed to fill in the English language gap, and prepare students to participate in academic exchange opportunities.

The Federal University of Minas Gerais (UFMG) has demonstrated leadership by developing one of the first English for academic purposes ${ }^{1}$ program within the Brazilian federal university system to prepare students to take part in exchange programs abroad. The courses began in August 2012, and were offered at a minimal expense; classes were free and students were only required to purchase the accompanying course book. The first phase of this research project consisted of a small sample from this group of learners. The IFA ${ }^{2}$ courses at UFMG are now in their fourth semester. Enrollment jumped from 180 to 350 students, and the course level went from three to five levels. In the first semester, the program only offered a certificate for those who passed the course; in the second semester the course became part of the university program, so the students could earn 4-credits if they successfully completed the course. This paper is the initial research from the first semester, and data from the second and

\footnotetext{
${ }^{1}$ In Portuguese: Inglês para Fins Acadêmicos (IFA).

${ }^{2}$ Inglês para Fins Acadêmicos (IFA).

Horizontes de Linguística Aplicada, ano 14, n. 1, 2015
} 
third semesters for a deeper qualitative and quantitative study is in preparation.

In order to better understand this scenario and the motivation these learners possess, the research project applies Dörnyei's (2005) Theory of the L2 Motivational Self System to Brazilian university students, predominantly non-language majors who plan to participate in the SWB program. In this way, the study is the first of its kind to apply the L2 motivational self system framework to Brazilian L2 learners studying English in a formal setting. The aim of the investigation presented in this paper is multi-purpose: first, the study maps IFA students' language identity and their motivation to learn English; second, it expands the use of the L2 motivational self system in relation to the population mentioned, and lastly, the study highlights the learner population as a target population of a federal educational policy aimed to benefit Brazil in the long-term.

The L2 motivational self system framework has already been empirically validated in diverse L2 contexts, such as Hungary (cf. DÖRNYEI; CLÉMENT, 2001; DÖRNYEI; CSIZÉR, 2002; KORMOS; CSIZÉR, 2008; CSIZÉR; KORMOS, 2009), Taiwan (DAI, n.d.), Indonesia (LAMB, 2012), Brazilian learners living in the US (MOTA; AZEREDO, 2009) and others (AZEREDO; BADGER, 2013) as an instrument for assessing students' motivation and other motivation-related constructs. However, there is still the need for more large-scale quantitative research contemplating motivation, L2 selves and L2 learning in different sociocultural contexts, different age groups, and also geographically distinct populations, as suggested by Kormos and Csizér (2008) and Csizér and Dörnyei (2005a). In this context, we hypothesized that the university students attending IFA courses would be motivated and show a defined ideal L2 self, as the main obstacles for their foreign scholarship is demonstrating English language proficiency. 
This research is interdisciplinary at its core, and it is rooted in Applied Linguistics in the area of Motivation, and it also concerns Brazilian higher educational policy, particularly as they relate to international education, shifting global dynamics and economic priorities. SWB is a large, capacity-building policy, in that Brazil is investing in intellectual and human resources to strengthen its domestic capabilities (McDONNELL; ELMORE, 1987). EAP is one policy tool designed to increase participation in the SWB program, a larger, federal policy.

In this paper, we provide a theoretical background to our study, followed by the description of the instruments used to collect data, and the data collection procedures. Next, we describe the findings concerning motivation, L2 attitude, socioeconomic background and ethnicity, and the relationships among these variables. Thirdly, we discuss the role that the EAP program plays within the broader SWB policy. Lastly, we report on how and to what extent these variables can impact student language learning achievements, and other policy considerations.

\section{Literature Review}

The L2 motivation construct has been in evidence in the SLA research field for decades. This is due to its central relevance in the process of language learning, as it is one of the stronger determiners of students' achievements. Certainly now in the $21^{\text {st }}$ century, with the global spread of English as a Lingua Franca (JENKINS, 2000), the interest in the motivational construct has been renewed.

These changes evidenced in the globalized world not only affect the world economy, but also have a direct impact within the field of education; in this case, with L2 language learning. For instance, there is a distinction between an $\mathrm{L} 2$ speaker and a native speaker; however, nowadays, in applied linguistics, the notion of 
English native speaker is dissipating, as an increasing number of students learn a second language with the purpose to communicate with other non-native speakers in an international setting (KORMOS; CSIZÉR, 2008).

The advent of English as an International language presents an issue to the key construct of L2 motivation research; namely, the notion of integrativeness/integrative motivation, a construct that emerged from the early studies on L2 motivation by Gardner and Lambert (1959). In their study, the concept of integrative orientation was characterized by a "willingness to be like valued members of the language community" (GARDNER; LAMBERT, 1959, p. 271, italics in original). Since the seminal work of 1959, the concept of integrative motivation has been the most relevant and productive in the SLA field. However, it currently has been source of much discussion and controversy, as the notion of integrativeness cannot cope with the idea of English as International language and its consequences. An attempt to address this issue is the theoretical shift proposed by Dörnyei (2010), in which the traditional conceptualization of motivation, specifically, the distinction between integrativeness and instrumental motivation is revisited.

The construct of L2 learning motivation was reshaped based on three seminal works. The first is (a) the one of Gardner and Lambert (1959) and Gardner (2001) in relation to the construct of integrative motivation. Integrative motivation comprises a positive attitude toward the L2 group and the need to interact with, and even become similar to, a valued member of that community. From Gardner's (2001) point of view, it implies a psychological and emotional identification with the speakers of the L2 community. On the other hand, Dörnyei (1990) claims that in the absence of the L2 group in the learners' immediate environment, the identification can be expanded to the cultural and intellectual values attached to the language, and even the actual L2 itself. 
The other two theories stem from the socio-psychological field; one of them is the (b) Self-Discrepancy theory of Higgins (1987). This theory establishes the notion of ideal-self, actual-self, and ought-to self. The first represents the qualities that a person would like to possess (e.g. aspiration, hopes, wishes); the second, is one's representation of the attributes that someone believes one actually possesses, and the latter refers to the qualities people believe that one's should or ought to possess (e.g. sense of duty, obligations, responsibilities) (HIGGINS, 1987). This theory defends the notion that motivation results from a person's wish to minimize the gap between one's ideal-self and one's actual-self, and also between one's actual-self and one's ought-to self. The last is the theory of the (c) Possible Selves by Markus and Nurius (1986). "Possible selves represent the individuals ideas of what they might become, what they would like to become, and what they are afraid of becoming, and thus provide a conceptual link between cognition and motivation" (MARKUS; NURIUS, 1986, p.954). Although changes were necessary to make the theory accurate with the new motivational thinking, and also to answer to the current understanding of English as a world language, the re-conceptualized version still holds the principles of the L2 field (DÖRNYEI, 2009).

Based on the theories mentioned above, Dörnyei proposes The Motivational Self System Framework. This approach draws an explicit connection between the individual self in the learning process and the individual motivation (DÖRNYEI; USHIODA, 2009). The construct of motivation is then explained as being part of the learner's self system. In this case, Dörnyei (2010) suggests that the L2 learning motivation is closely associated with the learner's ideal L2 self. Essentially, the Motivational Self System Framework is composed by three main aspects: the Ideal L2 self, the Ought-to L2 self and the L2 learning experience (cf. DÖRNYEI, 2005; CSIZÉR; DÖRNYEI, 2005a). 
The first component in this model is the Ideal L2 self, which represents one's ideal personal vision of the language speaker one would like to become; if there is evidence of a difference between one's current state and what one's desire as a competent L2 user, one may be motivated to do the necessary efforts to reach one's goal. Results of studies that have compared the ideal L2 self and integrativeness (RYAN, 2009; CSIZÉR; KORMOS, 2009) have suggested that the ideal L2 self correlates strongly with integrativeness. The ideal L2 self is the most important component of the model because it represents the ideal self image of the learner and his desire to become a competent speaker of the L2. The second component is the Ought-to L2 self.

The central idea of the ought-to self is that it holds not one's own expectations, but those of other people have about you (i.e., parents, teachers, significant others, and relatives). The third component is the L2 learning experience. This component is comprised of motives directly related to one's learning environment and experience (i.e., teacher, curriculum, material, language development). The motivational power of this construct seems to have the same strength as the ideal L2 self, as suggested by some findings (CSIZÉR; KORMOS, 2009); however, this aspect varies according to the context the participants are inserted, for instance; high school or college setting, urban or rural, and others.

At this moment, it is relevant to consider some of the previous studies that contemplated the motivational construct as proposed by Dörnyei, and which are relevant for the present study. The first is the longitudinal research by Dörnyei and Csizér (2002). The study investigated the language related attitudes and language learning motivation of 8,593 Hungarian high-school students. Results suggested that there are five intercorrelated dimensions to describe Hungarian students' L2 learning motivation disposition: integrativeness; instrumentality; direct contact with L2 speakers; cultural interest; and vitality of the L2 community. Another 
interesting finding is that, although French, Italian and German are quite popular languages in Hungary, students indicated expressively higher motivation towards learning English.

Another relevant study that applied Dörnyei's framework to a specific, international context is that of Dai (n.d.). The study investigated learners' self-identity change in response to EFL learners' motivation and language proficiency. The participants of this study were 94 Taiwanian EFL college students. Results of a regression-analysis showed that motivation types were correlated with self-identity changes on EFL learners, and also that learners with high language proficiency underwent significant effects on self-confidence and split changes.

The study by Mota and Azeredo (2009) investigated the motivation within the L2 motivational self system framework of ESL Brazilian workers-learners' living in the US. Results found suggested that, despite the time these participants have been learning English, their degree of integrativeness is low and their ideal L2 self is not clearly defined.

Lastly, a final study worth relating to our context is the one conducted by Lamb (2012). In this study, the author concentrated on high school Indonesian learners of English L2 motivation, and applies Dörnyei's framework to three different Indonesian settings: metropolitan, provincial and rural. Results suggested that motivation was found to be similar in strength and character in the metropolitan and provincial settings, but substantially different in the rural setting. It was also found that the language learning experience was the strongest predictor of both motivated learning behavior and L2 proficiency; however, the Ideal L2 self was only a significant factor for the metropolitan group of L2 learners.

The research findings presented above support the need for the current study, as the quest for further general understanding in the areas of motivation, ideal self, and the relationship of these constructs continues. Moreover, this framework can be combined with other specific circumstances or 
situations, such as English language and globalization, proficiency level, geographical and social context, specific learner populations, educational policy, international education and others, to shed light, interest, and greater understanding of the L2 motivational framework in specific contexts.

Therefore, considering the aspects discussed above related to integrativeness, the research findings, and the current thought around the motivation construct, which makes a direct connection between the L2 learning motivation and the notion of identity (the learner's ideal L2 self), this study aims to map IFA students' language identity and their motivation to learn English; to expand the use of the L2 motivational self system in relation to the population mentioned; and lastly, to highlight the learner population as a target population of a federal educational policy aimed to benefit Brazil for long-term goals.

\section{Method}

This is an exploratory, cross-sectional research project that investigated language learners from a major public university in the southeast of Brazil, UFMG. This university was selected because it is the first in the country to implement an EAP program as a response to the increasing demand for students' high-level English proficiency in order to prepare them successfully to participate in programs in foreign universities. UFMG offers 75 undergraduate majors and accommodates approximately 6,610 new students each year, without considering masters, doctoral, and specialization students. Foreign language is voluntary at UFMG, unless one's major requires a specific language. However, students need to have reading skills of Spanish or English for the entrance exam.

The IFA program's planning process started in early July 2012, and the actual classes started in October 2012 with 10 
classes and seven instructors. Potential participants took a placement test in order to be assigned to the appropriate level. The placement test was an adaptation of the paper-based TOEFL test (with no speaking or writing). The data for the investigation presented in this current paper was collected from four classes-two intermediate levels, and two advanced levels. Students' proficiency level corresponded to $\mathrm{B} 1$ and $\mathrm{C} 1$ according to the Common European Framework of Reference (CEF) (Council of Europe, 2001).

\subsection{Participants}

Forty-eight participants (26 males and 22 females) took part in this survey. All participants were university undergraduate students from different fields, with ages ranging from 19 to 27 . All reported having studied English before in a formal context (high school or private English courses). The majority of them started studying English at a young age, between 10 and 15 years old. None of them have lived in an English speaking country, and only two had visited the USA for brief periods, less than a month. Most of the participants indicated that they are taking the EAP course to improve their proficiency level in order to take the TOEFL test, and also to participate in the SWB exchange program. Students were not compensated for their participation in this study.

\subsection{Instrument}

Three different questionnaires were developed to collect data of the participants: demographic information, L2 learning, and ethnicity and socioeconomic backgrounds. One questionnaire was adapted from Dörnyei and Clement (2001) to collect information regarding attitudes and motivation toward L2 learning. The assessment materials included a TOEFL placement 
test, quiz and student essays. The instruments are explained below:

\subsubsection{Demographic questionnaire}

This was designed to collect background information related to schooling in general, foreign languages, and participants' personal information. It consisted of 13 short-answer items. It was also included in this questionnaire a section for the participants to give/or not their consent to use the data collected. It took between 10-15 minutes to complete the form (see Appendix A).

\subsubsection{Motivation questionnaire}

As previously mentioned, this questionnaire was adapted from Dörnyei and Clement (2001), who designed and applied the instrument in their large-scale survey with Hungarian students. Since then, this instrument has been largely used and adapted in the linguistic field (CSIZÉR; DÖRNYEI, 2005a; KORMOS; CSIZÉR, 2008; RYAN, 2009; MOTA; AZEREDO, 2009). The adapted version, of this current study, consists of three sections, and a total of 36 items. On the first section, participants were required to express their opinion about five target languages (German, French, Japanese, English, and Spanish), and six L2 communities (France, England, Japan, Germany, Spain, and The United States). It was used a 5-point Likert scale, 5 being the most positive and 1 the least positive. The second section consisted of eight statements about language learning process and environment, and participants' were required to agree or disagree with them, following an agreement scale. The third section had seven open-ended items tackling the participants' language learning background. It took between 20-30 minutes to complete the form. (see Appendix B). 


\subsubsection{Ethnicity and Socio-economic questionnaires}

The questionnaire concentrated on capturing participants' ethnicity and the average family monthly income. It consisted of four items, two open-ended and two closed questions. The time required to complete the form was between 10-15 minutes. (see Appendix C).

\subsubsection{TOEFL placement test}

Prospective IFA students were selected by means of the paper-based TOEFL placement test covering section 1 (listening comprehension with 50 items), section 2 (structure and written expression with 40 items), section 3 (reading comprehension with 50 items). Each section was time constrained being 35 minutes, 25 minutes and 55 minutes respectively. The cut off score was 459; therefore, all the candidates who obtained a score lower than the one specified were not able to enroll to take IFA courses. For this study, students' scores were between 460 and 585 .

\subsection{Procedures}

The first step in this study was to administer and evaluate the placement test. Participants were then asked to read and sign a consent form authorizing permission to use their information. Next, participants were encouraged to complete each questionnaire, in class, on different days following the instructors' schedule. The days were staggered as to not overload the participants. Each questionnaire was later codified to protect participant's identity. If a participant did not complete all three questionnaires, then the subject was automatically eliminated from the study.

The data was initially analyzed by using the following procedures: codification of the participants, labeling of each one 
of the three questionnaires, reading and codifying the items on each questionnaire and, entering data on a spreadsheet. After this process, a computer program was used to compile and chart the data.

\section{Results and discussion}

This research investigates attitude and motivation to learn languages. For this, we concentrated on the motivation sources that are situation-specific, and also motivation that can be rooted in the EAP students' past experiences (DÖRNYEI, 2000; DÖRNYEI, 2001).

The first part of the study was to screen the sample and identity the profile of the IFA students regarding: age, major, L2 level, years of exposure to the L2, ethnicity, and socioeconomic background. The majority of the students from the IFA classes come from the hard-sciences; only $2 \%$ are from humanities and health areas. Actually, this was an expected result as the main target of the SWB program is the hard-sciences, and the portion of the scholarship allocated for the humanities was cut with very few exceptions (MARTINS, 2013).

In terms of ethnicity, our findings (Fig. 1) are corroborated by a survey conducted by the National Association of Leaders of the Federal High Education Institutions (ANDIFES) in 2010 and 2011. According to this national survey, $53.93 \%$ of the students from the federal institutions declare themselves as white, followed secondly with mestiços (32. 8\%), and thirdly with black $(8.72 \%)^{3}$. Regarding family income, the current study applied different measures to access the information. We used the minimum wage in the year of 2012, which was R $\$ 667,00$ (around US\$294.00)

\footnotetext{
${ }^{3}$ The ANDIFES (2011) research had the category yellow and pardo for mestiço.
} 
while the ANDIFES study applied a scale in relation to goods and services to determine the relative family income. However, when we examine the family income related to economic class, our data corroborates with the national survey. According to the ANDIFES data, the Classes B1 and B2 (which represent the income established on the current research - between $\mathrm{R} \$ 2.500,00$ and $\mathrm{R} \$ 4.400,00$ ) are the most representative student background incomes found at Brazilian federal institutions. This fact is especially salient at the institutions in the southeast of Brazil.

\section{Ethnicity}

\begin{tabular}{|l|c|c|}
\hline \multicolumn{1}{|c|}{ Ethnicity } & $\mathrm{n}$ & $\%$ \\
\hline White & 25 & $51.02 \%$ \\
\hline Afro-Brazilian & 3 & $6.12 \%$ \\
\hline Mestiço & 17 & $34.69 \%$ \\
\hline Native-Brazilian & 0 & $0.00 \%$ \\
\hline Other & 4 & $8.16 \%$ \\
\hline Total & 49 & \\
\hline
\end{tabular}

Wage

\begin{tabular}{|c|c|c|}
\hline Wage & $\mathrm{n}$ & $\%$ \\
\hline From 0 to 3 & 4 & $8.33 \%$ \\
\hline From 4 to 7 & 19 & $39.58 \%$ \\
\hline From 8 to 11 & 12 & $25.00 \%$ \\
\hline From 12 to 15 & 7 & $14.58 \%$ \\
\hline From 16 to 19 & 3 & $6.25 \%$ \\
\hline From 20 to 23 & 2 & $4.17 \%$ \\
\hline 24 or more & 1 & $2.08 \%$ \\
\hline Total & 48 & \\
\hline
\end{tabular}

Figure 1: Ethnicity and socioeconomic data

Source: Elaborated by the authors

The second part of the study consisted of investigating the participants' language motivation related to language preference, L2 ideal self, language orientation, attitudes towards the L2, family involvement and other cognitive aspects that may influence learners' motivation. 
English is by far the leading language preference compared to the other language options (Fig. 2). This confirms the desire of the participants to learn the language, and signals that they are positive about the language they chose to study.

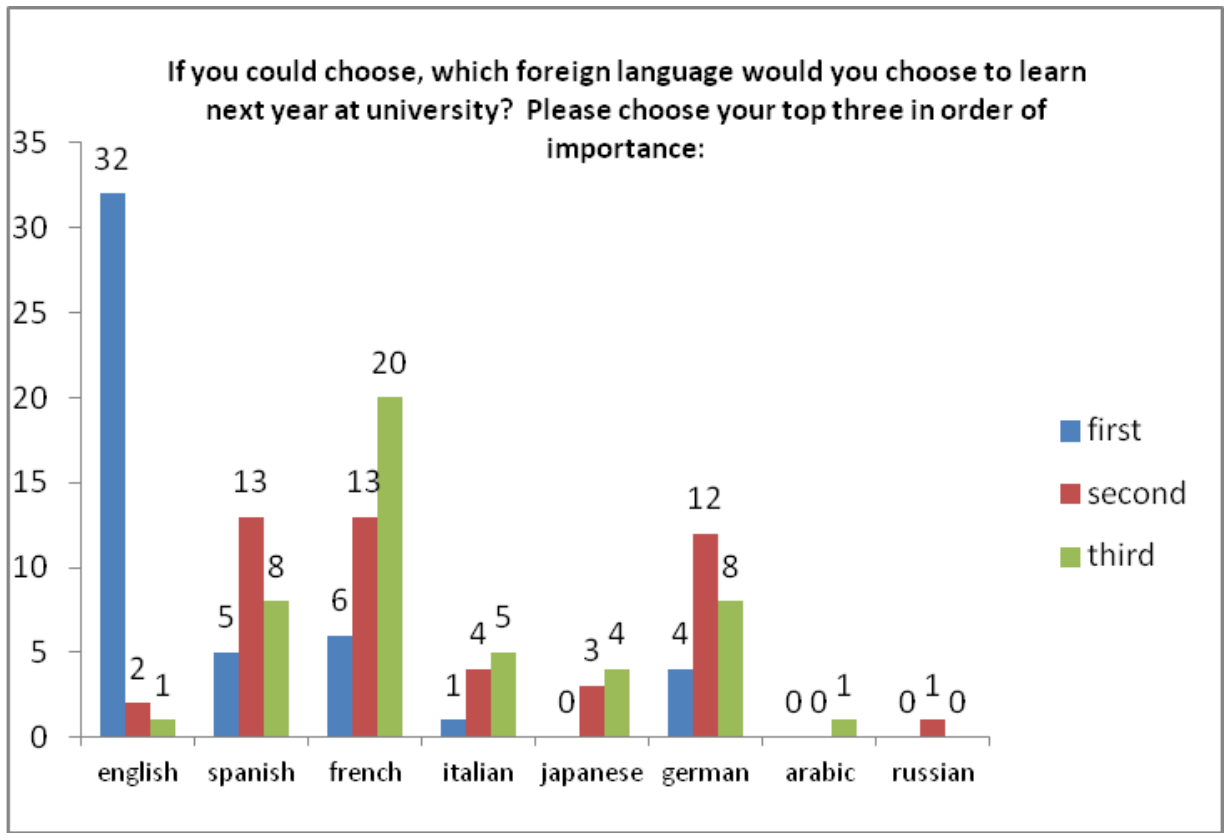

Figure 2: Language preference

Source: Elaborated by the authors

Generally speaking, Brazilian university students believe that learning another language is relevant for their future careers, as can be noticed in Figure 3. Participants were asked questions related to these 5-languages (English, French, German, Japanese, and Spanish), and were asked to rank them on a 5-point rating scale from 0 to 5 , with 0 meaning no relevance, and 5 being of high relevance. Analyzing Figure 3, one can observe that, although learning an L2 is relevant for these participants, English is considered the most relevant language, while French, German Horizontes de Linguística Aplicada, ano 14, n. 1, 2015 
and Spanish hold approximately the same relevance, and Japanese holds the least relevance.

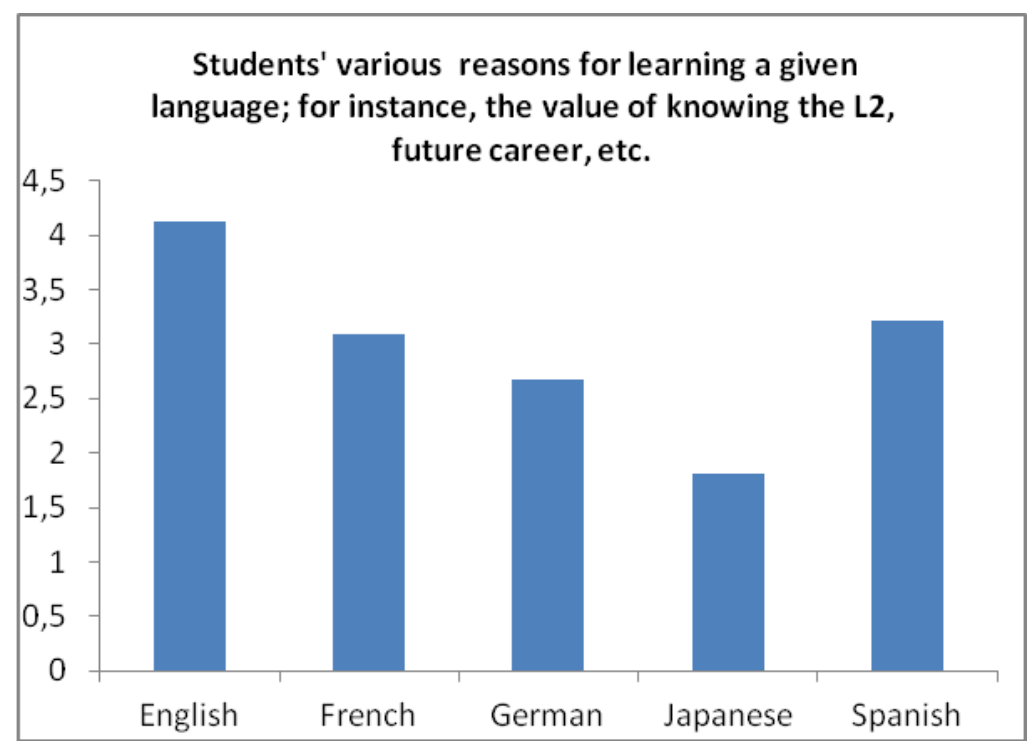

Figure 3: Language orientation

Source: Elaborated by the authors

Language learning attitude is related to the extent to which participants connect to the language they are learning, and how positive their relationship is to that language. Observing Figure 4, one can notice that students indicated having a more positive attitude toward English, followed by Spanish, French and German. This pattern is relatively the same as can be observed in Figure 3. This trend corroborates participants' intentions: since they chose to study English, they believe it is the most important language for their career, and they are satisfied with their choice. The same applies to the other four languages, but on a lesser scale. 


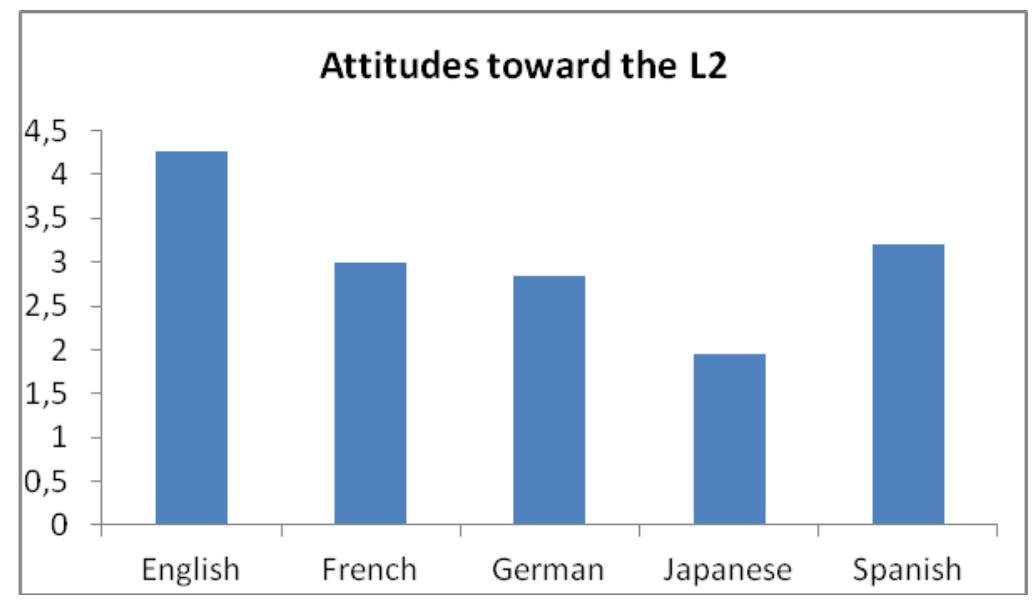

Figure 4: Attitudes towards the L2 Source: Elaborated by the authors

Similarly, participants were prompted to answer questions regarding their commitment to learn the languages, the amount of effort they were ready to make to achieve their goal. Once again, the data demonstrates that English is the top priority when compared to the other four languages (see Fig. 5). 


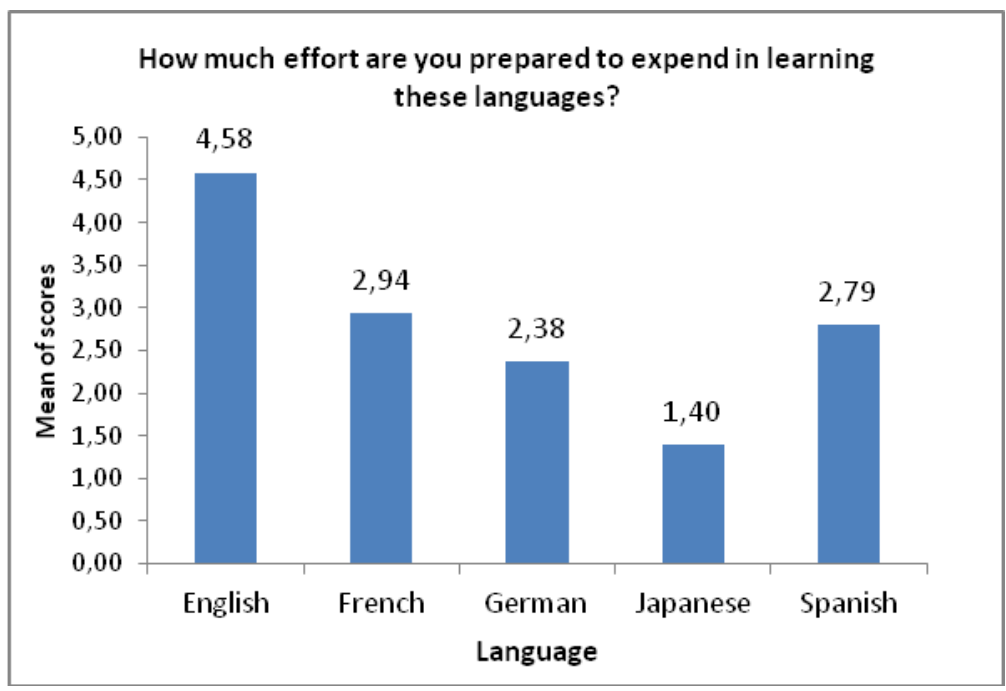

Figure 5: Intended effort

Source: Elaborated by the authors

It is clear that the participants are determined to learn English in order to reach their goal, as indicated by the results described. However, it is relevant to address other complex aspects related to language identity--for instance, fear of assimilation. This is a variable that represents the extent to which participants believed that learning and using a foreign language detracts from their native language and culture. In order to capture this variable, the participants were asked to answer a question using a 5-point Likert scale.

As represented in Figure 6, the majority of the participants of this study do not feel that they will lose their L1 cultural identify by learning a foreign language. The relative values on the top of the bars represent all the five languages surveyed on this study. 


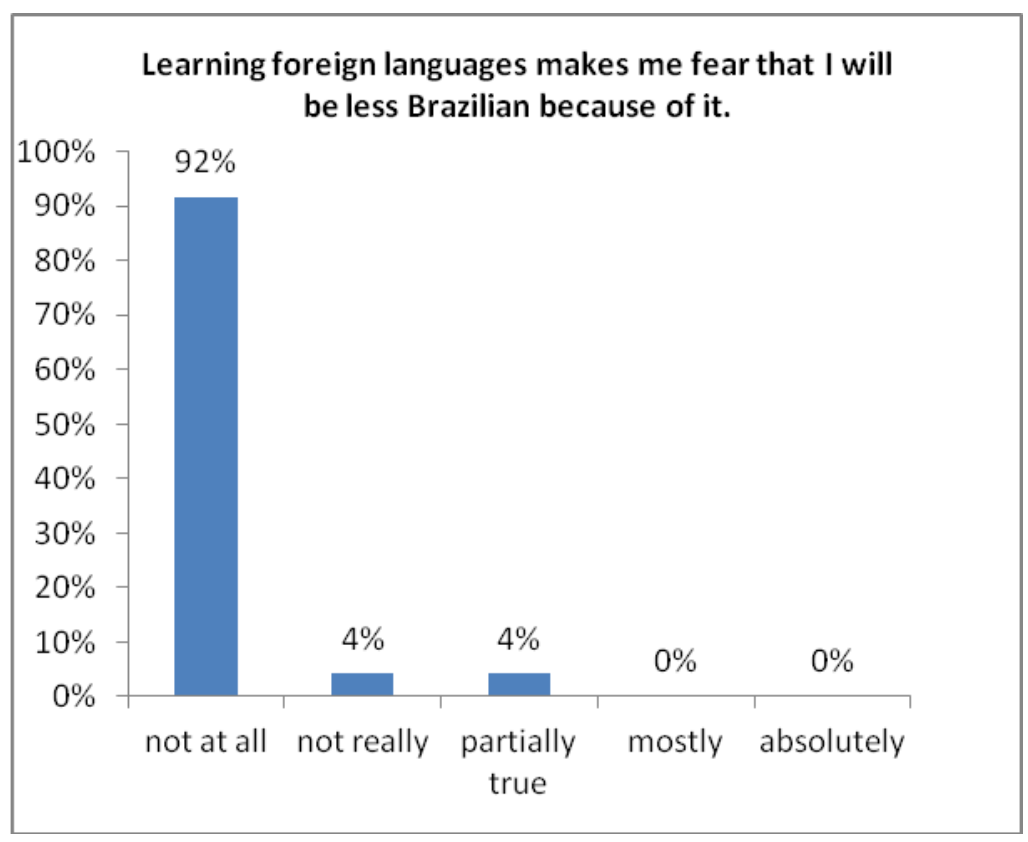

Figure 6: Fear of assimilation

Source: Elaborated by the authors

Another relevant aspect is linguistic self-confidence. This represents the students' views on how easily and successfully they will be able to learn the L2. According to the results (Fig. 7), the participants demonstrated having high linguistic self-confidence $(60 \%)$; however, it is important to notice that $31 \%$ do not demonstrate the same confidence about their success on learning the desired L2. 


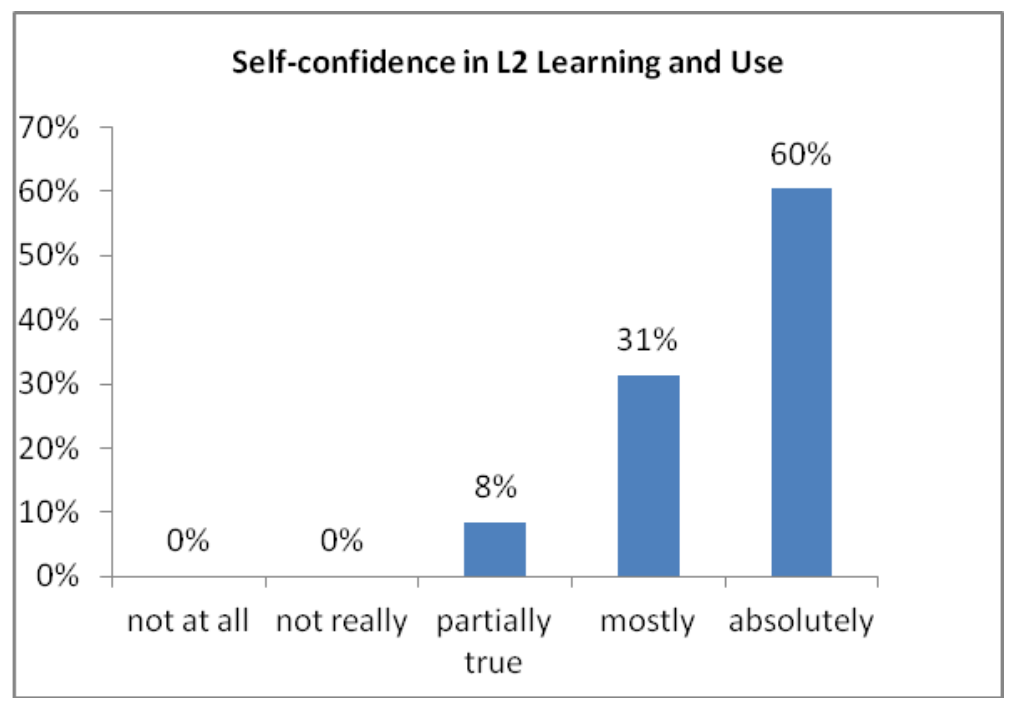

Figure 7: Self-confidence in L2 learning and use Source: Elaborated by the authors

Figure 8 represents the attitude of participants' immediate environment concerning the relevance of learning English. The findings suggest that the opinion of family and friends is highly meaningful for the participants (Fig. 8). This aspect was assessed by three statements, similar to my parents do not consider foreign languages important academic subjects (SEE APPENDIX B). Participants had to answer the statements on a 5-point Likert scale, indicating to what extent the statements characterized them. 


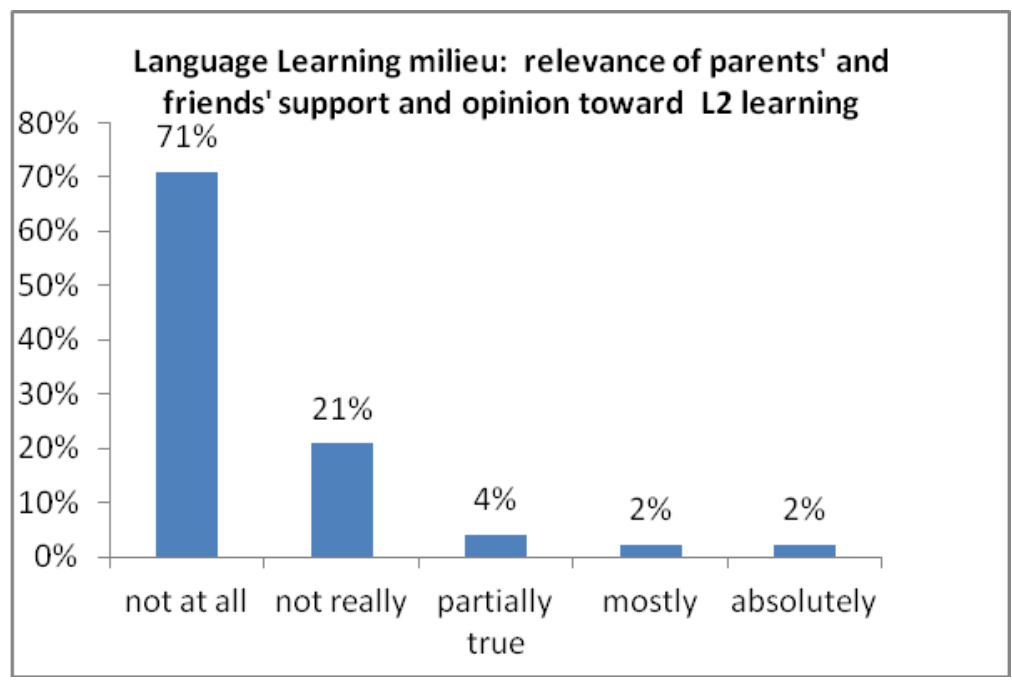

Figure 8: Language learning milieu

Source: Elaborated by the authors

The results presented here demonstrated that the learners who are taking the IFA courses at UFMG are motivated and committed to make the necessary effort to learn English. These participants possess a well-defined ideal L2 self, and indicate a positive attitude towards the $\mathrm{L} 2$ and the $\mathrm{L} 2$ community.

Regarding ethnicity and socioeconomic background, our students did not represent a wide or diverse range of differentiation in the categories of ethnicity or socioeconomic status, and does not match the socioeconomic or ethnic demographics of the country at large (MARTINS, 2013). This inequitable imbalance leads one to question larger systemic issues and concerns for Brazil, particularly in the design and implementation of federal educational policy. For example, Brazil should consider policies that reach the general population earlier, through elementary and secondary education, rather than creaming the policy to benefit white, middle class university 
students who are already benefiting from the system through free higher education (SCHNEIDER; INGHRAM, 1991).

\section{Conclusions}

Initially, the study mapped students' language identity and their motivation to learn English; second, it expanded the use of the L2 motivational self system in relation to the population mentioned; and lastly, the study highlighted the learner population as a target population of a federal educational policy aimed to improve Brazilian university students' second language skills and academic experience over the long-term.

As stated before, our data indicated that the participants of the study possess a well-defined ideal L2 self, a positive attitude toward the L2 and the L2 community and a motivated L2 learning behavior. From our results we can conclude that the investigated learners are highly motivated, ready and committed to make the necessary effort to learn the language and achieve their goal. The effort and commitment to learning the language were identified by the factors attitude toward the language learning and ideal L2 self. This specific finding is corroborated by the study of Kormos and Csizér (2008).

Our findings corroborate with our participants' major interest and motivation to learn the English language, and support the results found in relation to the participants' main goal of achieving a determined level of proficiency as measured by the TOEFL language test. This is relevant to our study because the findings suggest that part of the Ideal L2 self results is related to participants' language development. Similarly to Lamb's (2012) findings, research that combines the L2 motivational framework with diverse geographical and social contexts lends credibility and understanding to Motivational theory. 
Specifically, as EAP is an offset program designed to expand participation for the larger SWB program, it is relevant to examine the EAP program from a systemic standpoint. A clearer understanding of the program goals, participants, stakeholders, and other policy data can benefit the program and its goals (SCHNEIDER; INGHRAM, 1991). Furthermore, as policies are designed and implemented, a systemic analysis can draw conclusions as to the effectiveness of the overall policy design and implementation (McDONNELL; ELMORE, 1987).

When we examined our student socioeconomic and ethnic demographics, we noticed that this policy is largely benefiting the Brazilian students already most likely to be successful, which is known as policy creaming (SCHNEIDER; INGHRAM, 1991). Creaming in policy design is logical, as it is the easiest and most obvious way for success, but from an educational and societal standpoint, it is not equitable. It is recommended that the Brazilian government design and implement broader educational policies that reach a more diverse socioeconomic student population.

The main limitations of the study are that the students were only from one geographical region (a capital city in the Southeast) and from one specific federal university, and therefore do not represent the wide variety of Brazilian federal university students' potential candidacy to the SWB program. Thus, we speculate that in different regions of Brazil where people may not have extensive access and exposure to English language and culture, one may find different results in relation to the ideal L2 self, for example. A second limitation is that the small number of participants could not yield representative inferential results. An upcoming study includes a larger sample size to produce generalizable results. However, this initial research, while interpretative, was based on a well-established research tradition and applied validated instruments to collect data. Thus, the results 
found are relevant, and we recognize the need for further research applying robust, inferential methods.

Future research should examine the EAP students in a longitudinal way, and attempt to trace the long-term impact the EAP course has on their language proficiency, as well as the necessary time required to be successful with the TOEFL test. Also students' proficiency levels are being examined within the EAP program, according to student class/group levels, to his/her area of study, and to track individual students who continued in the EAP program. These results can assist with the EAP program's overall effectiveness. In addition, we recommend that others conduct studies that focus on alternate demographics and/or contexts, while still employing the L2 motivational self system framework. For example, one possible demographic would be to study Brazilian high school students who are studying English. Again, continued research such as these would contribute not only to a more profound understanding of language motivation and specific populations of learners, but also offers recommendations for improved, equitable educational policy.

\section{Acknowledgements}

We thank IFA students for their generous participation on this survey, and we are grateful to two anonymous reviewers for their comments and suggestions.

Both authors contributed equally to this article. The order of authors' names is strictly alphabetical. An earlier version of this article was presented at the annual ABRALIN conference held in Natal, Rio Grande do Norte, Brazil in January 2013 and at the Matters of the Mind: The Psychology of Language Learning in Graz, Austria, in May 2014. 


\section{References}

AZEREDO, Flávia; BADGER, Shellwyn. Motivation, identity and socio-economic backgrounds: a study with English for academic purposes learners. In: CONGRESSO INTERNACIONAL DA ABRALIN, 23, 2013. Natal. Anais... Natal, 2013.

. Dynamics of language motivation: a study with EAP learners. In: MATTERS OF THE MIND: THE PSYCHOLOGY OF LANGUAGE LEARNING CONFERENCE, 1, 2014. Graz. COUNCIL OF EUROPE. Common european framework of reference for languages: learning, teaching, assessment. Cambridge, Cambridge University Press, 2001.

CSIZÉR, Kata. DÖRNYEI, Zoltán. Language learners' motivational profiles and their motivated learning behaviour. Language Learning, v. 55, n. 4, p. 613-659, 2005 a.

. The internal structure of language learning motivation and its relationship with language choice and learning effort. The Modern Language Journal, v. 89, p. 19-36, 2005b.

; KORMOS, Judit. Learning experiences, selves and motivated learning behaviour: a comparative analysis of structural models for Hungarian secondary and university learners of English. In: DÖRNYEI, Zoltán; USHIODA, Ema. (Eds.). Motivation, language identity and the L2 self. Bristol: Multilingual Matters, 2009. p. 98-119.

DAI, Mei-Hsia. (n.d.). The relationships of language learning motivation, language proficiency and self-identity changes in EFL learning context. Available at: 
<www.ntnu.edu.tw/acad/rep/r97/a4/a407-1.pdf〉. Access on: 26 Sept. 2015.

DÖRNYEI, Zoltán. Conceptualizing motivation in foreign language learning. Language Learning, v. 40, p. 46-78, 1990.

Motivation in action: Towards a process-oriented conceptualization of student motivation. British Journal of Educational Psychology, v. 70, p.519-538, 2000.

. New themes and approaches in L2 motivation research. Annual Review of Applied Linguistics, v. 21, p. 43-59, 2001.

. The psychology of the language learner: individual differences in second language acquisition. Mahwah, NJ: Lawrence Erlbaum, 2005.

. The L2 motivational self system. In DÖRNYEI, Zoltán; USHIODA, Ema. (Eds.). Motivation, language identity and the L2 self. Bristol: Multilingual Matters, 2009. p. 9-42.

Researching motivation: from integrativeness to the ideal L2 self. In: HUNSTON, Susan; OAKEY, David. (Eds.). Introducing Applied Linguistics: concepts and skills. London: Routledge, 2010. p. 74-83.

; CLÉMENT, Richard. Motivational characteristics of learning different target languages: results of a nationwide survey. In DÖRNYEI, Zoltán; SCHMIDT, Richard.(Eds.). Motivation and second language acquisition. Honolulu: University of Hawaii Press, 2001. p.399-432. 
; CSIZÉR, Kata. Some dynamics of language attitudes and motivation: results of a longitudinal nationwide survey. Applied Linguistics, v. 23 n. 4, p. 421-462, 2002.

; SCHMIDT, Richard. (Eds.). Motivation and second language acquisition. Honolulu: University of Hawaii Press, 2001. p. 1-20.

; USHIODA, Ema. (Eds.). Motivation, language identity and the L2 self: future research directions. Bristol: Multilingual Matters, 2009. p. 350-356.

GARDNER, Robert. (2001) .Integrative motivation and second language acquisition. In: GARDNER, Robert; LAMBERT, Wallace. Motivational variables in second language acquisition. Canadian Journal of Psychology, v. 13, p. 266-272, 1959.

HIGGINS, Edward. Self-discrepancy: a theory relating self and affect. Psychological Review, v. 94, p. 319-340, 1987.

JENKINS, Jennifer. The phonology of English as an international language. Oxford: Oxford University Press, 2000.

KORMOS, Judit; CSIZÉR, Kata. Age-related differences in the motivation of learning English as a foreign language: attitudes, selves, and motivated learning behavior. Language Learning, v. 58, n. 2, p. 327-355, 2008.

LAMB, Martin. A self-system perspective on young adolescents' motivation to learn English in urban and rural settings. Language Learning, v. 62, n. 4, p. 997-1023, 2012.

MARKUS, Hazel; NURIUS, Paula. Possible selves. American Psychologist, v. 41, p. 954-969, 1986.

Horizontes de Linguística Aplicada, ano 14, n. 1, 2015 
MARTINS, Michele. Por que o programa Ciência sem Fronteiras não contempla estudantes das Ciências Humanas? Assessoria de Comunicação da Universidade Federal de Goiás, VII, v. 56, março, 2013. Available at: <http://www.jornalufgonline.ufg.br/pages/44406>. Access on: 4 Nov. 2015.

MCDONNELL, Lorraine; ELMORE, Richard. Getting the job done: alternative policy instruments. Educational Evaluation and Policy Analysis, v. 9, n. 2, p. 133-152, 1987.

MOTA, Mailce; AZEREDO, Flávia. Aprendizagem de L2, motivação e identidade: um estudo com brasileiros que residem no exterior. Cadernos do IL, v. 38, p. 22-42, 2009. Available at: $<$ http://www.seer.ufrgs.br/cadernosdoil/>. Access on: 29 Sept. 2015.

Perfil socioeconômico e cultural dos estudantes de graduação das universidades federais brasileiras. In: FÓRUM NACIONAL DE PRÓ-REITORES DE ASSUNTOS COMUNITÁRIOS E ESTUDANTIS. Brasília: 2011. Available at: $<$ http://www.prace.ufop.br/novo/pdfs/publicacoes/Relatorio\%20 Nacional.pdf $>$. Access on: 29 Sept. 2015

RYAN, Stephen. Self and identity in L2 motivation in Japan: the ideal L2 self and Japanese learners of English. In: DÖRNYEI, Zoltán.; USHIODA, Ema.(Eds.). Motivation, language identity and the L2 self. Bristol: Multilingual Matters, 2009. p. 120-143. SCHNEIDER, Anne; INGHRAM, Helen. The choice of target populations. Administration \& Society, v. 23, n. 3, p. 333-356, 1991. 


\section{Appendix A}

Read the questions below and answer them with your information.

1) Name:

Date:

E-mail:

Phone number:

2) How old are you?

3) What's your nationality?

4) What's your first language?

5) Are you an undergraduate student? yes ( ) no ( )

i) what's your course at UFMG?

6) How long have you been studying English?

7) Why exactly are you studying English at this moment?

8) What are your goals with this English course?

9) Have you lived abroad? yes ( ) no ( ) where? How long?

10) Do you speak any other language? yes ( ) no ( ) which ones?

11) In the next section I would like you to put a number for each item, from 1 to 5 .

$$
5=\text { perfect } 4=\text { really } \operatorname{good} \quad 3=\operatorname{good} 2=\operatorname{not} \operatorname{sog} \operatorname{good} \quad 1=\operatorname{bad}
$$


How is your...
a) Listening ( )
b) Speaking ( )
c) reading ( )
d) writing ( )

12) In a scale from 1 to $5, \underline{1}$ being not difficult and $\mathbf{5}$ being very difficult, How difficult is this skill for you?

\begin{tabular}{ccccc}
1 & 2 & 3 & 4 & 5 \\
not difficult & & & very difficult \\
\hline
\end{tabular}
a) Listening ( )
b) Speaking ( )
c) reading ( )
d) writing ( )

13) Take a look at the chart below and think about the following questions:

$\begin{array}{ccccc} & \text { A2 } & \text { B1 } & \text { B2 } & \text { C1 } \\ \text { A1 } & 337 \text { a } 459 & 460 \text { a } 542 & 543 \text { a } 626 & 627 \text { a } 677 \\ <337 & (50 \text { a } 67 \%) & (68 \text { a } 80 \%) & (81 \text { a } 92 \%) & (93 \text { a } 100 \%)\end{array}$
a) Where are you in the chart?
A1 ( ) A2 ( ) B1 ( )
B2 ( )
C1 ( )
b) How far would you like to go? A1 ( ) A2 ( ) B1 ( )
B2 ( ) C1 ( )
c) How long will you take you to get there? months years
d) How far do you think you can get after this semester of course?
A1 ( ) A2 ( )
B1 ( ) B2 ( )
C1 ( )
e) How much time and dedication will you need to achieve you goal?

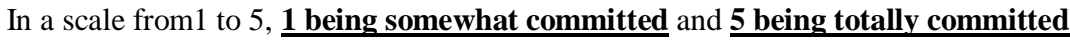

\begin{tabular}{ccccc}
1 & 2 & 3 & 4 & 5 \\
Somewhat committed & & & & $\begin{array}{c}5 \\
\text { totally committed }\end{array}$ \\
\hline
\end{tabular}

f) How committed are you to this course? 1( ) 2( ) 3( ) $4($ ) 5( )

I hereby give permission for all of my written production and survey materials in this English course to be used for research purposes. 
Date:

Name:

Signature :

\section{Appendix B}

Language orientation questionnaire

date:

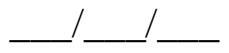

Name:

Teacher:

Class:

We request your help by answering the following questions concerning foreign language learning. We are interested in your personal opinion. Please give your answers sincerely as only this will guarantee the success of the investigation. Thank you very much for your help.

1. In the following section please mark 1 to 5 .

5 = very much,

$$
4 \text { = quite a lot, }
$$$$
3=\text { so-so, }
$$

$2=$ not really,

$1=$ not at all,

$0=$ not familiar with

Please put one whole number in each box and do not omit any boxes, thank you.

\begin{tabular}{|c|c|c|c|c|c|}
\hline & German & French & Japanese & English & Spanish \\
\hline $\begin{array}{l}\text { 1. How much do you like } \\
\text { these languages? }\end{array}$ & & & & & \\
\hline $\begin{array}{l}\text { 2. How much do you think } \\
\text { knowing these languages } \\
\text { would help you to become }\end{array}$ & & & & & \\
\hline
\end{tabular}

Horizontes de Linguística Aplicada, ano 14, n. 1, 2015 
Flávia A. Cerqueira; Shellwyn Badger

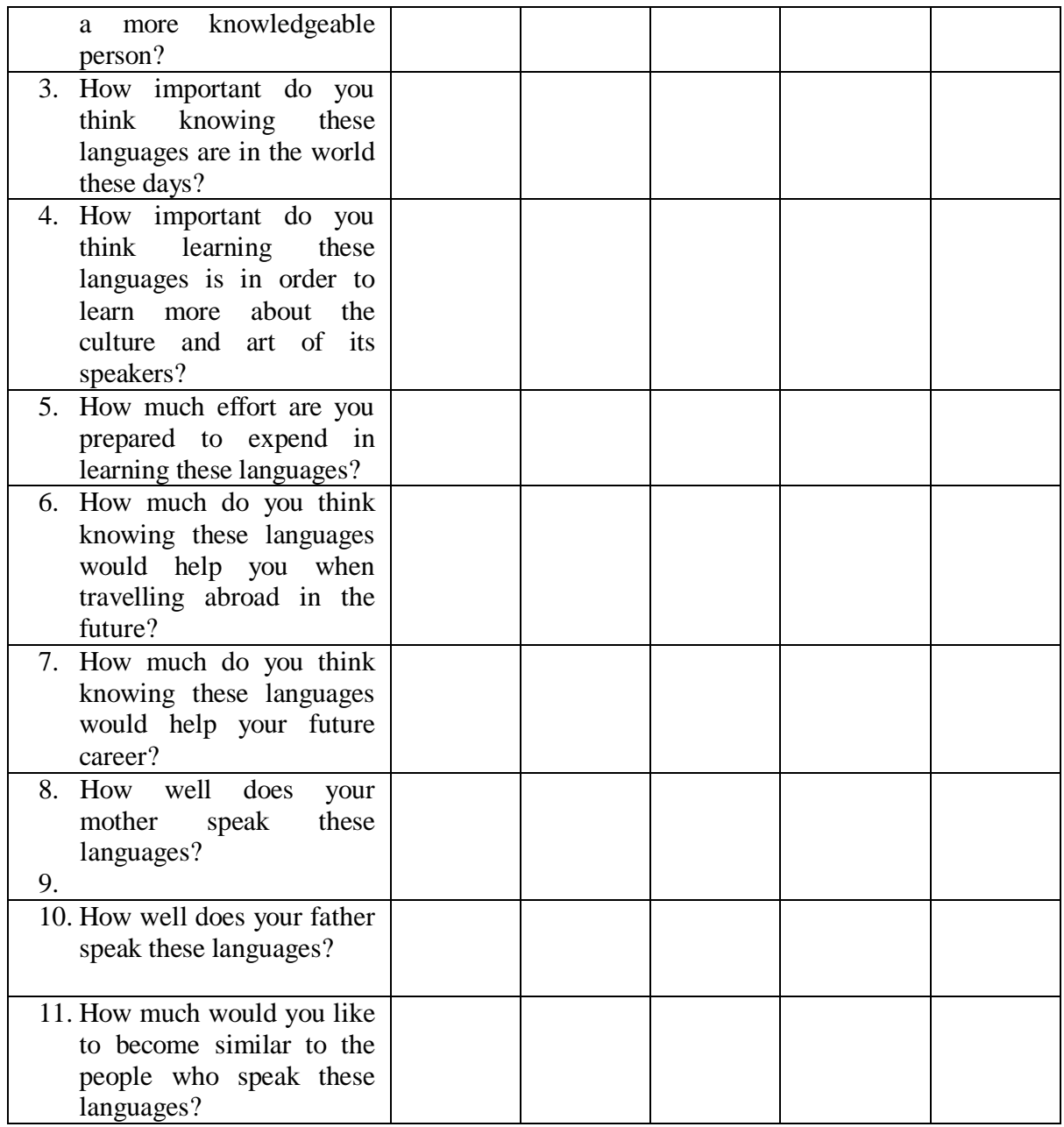

\begin{tabular}{|ll|l|l|l|l|l|l|}
\hline & France & England & Japan & Germany & Spain & USA \\
\hline 12. & $\begin{array}{l}\text { How much would you like } \\
\text { to travel to these } \\
\text { countries? }\end{array}$ & & & & & & \\
\hline 13. & $\begin{array}{l}\text { How wealthy and } \\
\text { developed do you think } \\
\text { these countries are? }\end{array}$ & & & & & & \\
\hline
\end{tabular}

Horizontes de Linguística Aplicada, ano 14, n. 1, 2015 


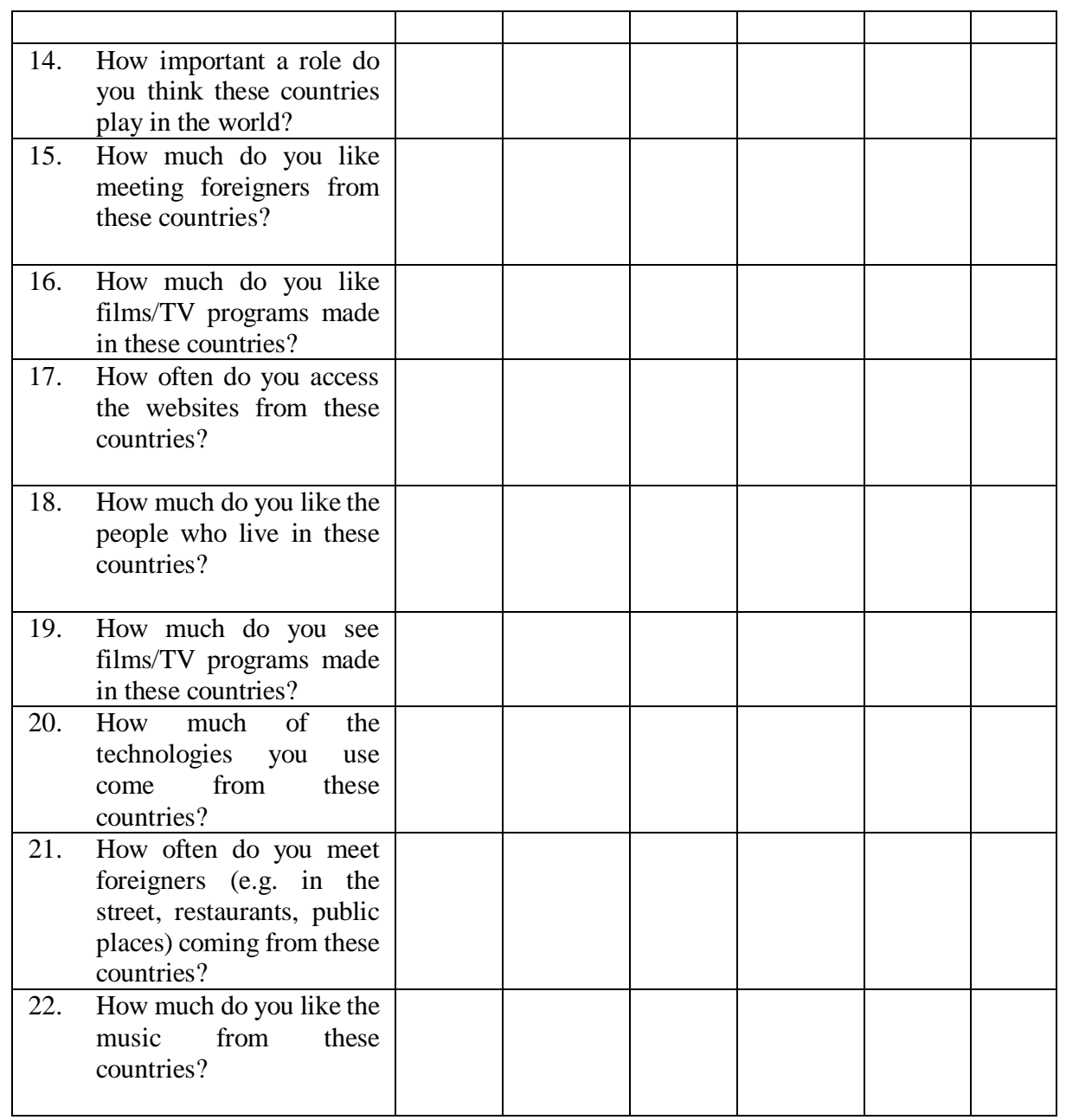

\section{II - Next, please mark an ' $\mathrm{X}$ ' in the box which best expresses how true the statement is about your feelings or situation.}

\begin{tabular}{|l|l|c|c|c|c|}
\hline & $\begin{array}{c}\text { Not at } \\
\text { all true }\end{array}$ & $\begin{array}{c}\text { Not } \\
\text { really } \\
\text { true }\end{array}$ & $\begin{array}{c}\text { Partly } \\
\text { true, } \\
\text { partly } \\
\text { untrue }\end{array}$ & $\begin{array}{c}\text { Mostly } \\
\text { true }\end{array}$ & $\begin{array}{c}\text { Absolu } \\
\text { tely } \\
\text { true }\end{array}$ \\
\hline 22. I am sure I will be able to & & & & & \\
\hline
\end{tabular}


Flávia A. Cerqueira; Shellwyn Badger

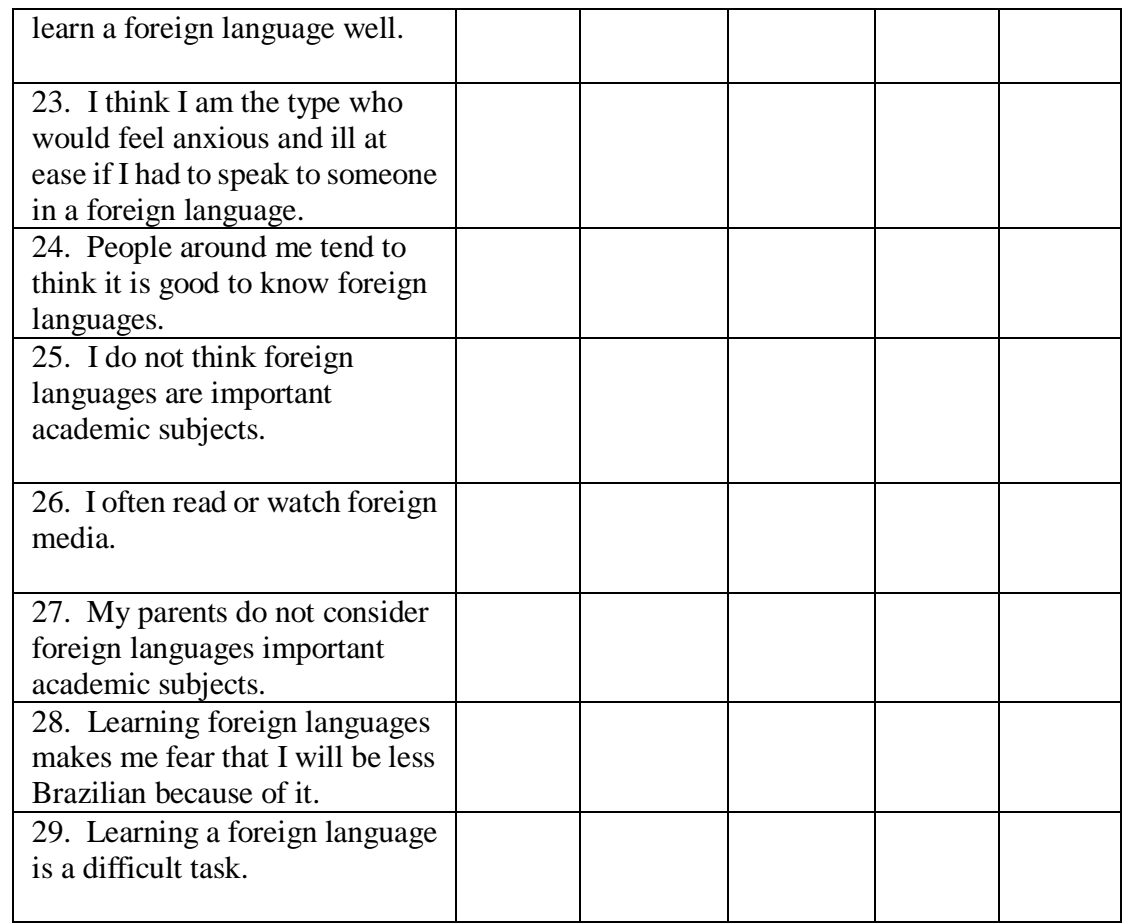

\section{Finally, please answer the following personal questions.}

30. If you could choose, which foreign language would you choose to learn next year at university or work? Please choose your top three in order of importance:

1.

2.

3.

31. Circle your gender: ( ) Female ( ) Male

32. What foreign languages are you learning at the university? 
33. Which, if any, foreign languages have you learned outside of the university?

34. At what age did you begin learning a foreign language?

35. Have you ever been abroad for longer than six months?

36. If so, where?

Thank you for your time and input.

\section{Appendix C}

1) Name:

Class: IFA

Instructor:

E-mail:

Phone number:
Date: I 

a) ( ) White (European)
b) ( ) Afro-Brazilian
c) ( ) Mestiço
d) ( ) Native-Brazilian (índio)
e) other(s )

4) Considering that one minimum wage salary in Brazil is $R \$ 667,00$ per month, what amount best describes your family's current cumulative household income?

a) ( ) from 0 to 3 salaries

b) ( ) from 4 to 7 salaries

c) ( ) from 8 to 11 salaries

d) ( ) from 12 to 15 salaries

e) ( ) from 16 to 19 salaries

f) ( ) from 20 to 23 salaries

g) ( ) 24 salaries or more

Submetido em: 28/09/2014 Aceito em: 04/05/2015

Título: Motivação e atitude linguística: um estudo com aprendizes de inglês para fins acadêmicos 